\title{
Development of Pharmaceutical Industry in Senegal.
}

\author{
Ndao $Y^{* 1}$, Diarra $\mathbf{M}^{2}$ \\ 1. Dr Youssou NDAO, Laboratory of Galenic and Legislation, Faculty of Medicine, Pharmacy \\ and Dentistry (F.M.P.O.), University Cheikh Anta Diop of Dakar (U.C.A.D.) \\ 2. Mounibé DIARRA, Pharmaceutical Physics Laboratory, Faculty of Medicine, Pharmacy and \\ Odontology, University Cheikh Anta Diop of Dakar (U.C.A.D.), Postbox 5005, Dakar-Fann, \\ Sénégal.
}

\begin{abstract}
Pharmaceutical industry in France stems from pharmacy practice and the State trusted pharmacist who had to control his company. Beginning in 1941, state gradually regulated and then controlled all activities of the drug industry, because of major impact of its products on Public Health. In Senegal, these old provisions have been taken over by article L596 of Book V. Pharmaceutical industrial sector is dependent on foreign manufacturers, where $85 \%$ of our drug needs are imported. The objective of our publication is to contribute to the development of local pharmaceutical industry. To achieve this, we have reviewed the literature on pharmaceutical industry and certain provisions of OHADA uniform act that encourage creation of pharmaceutical companies. US market remains the largest with $41 \%$ of the world market and Africa is the second most dynamic market with an average annual growth rate of more than $10 \%$. In West Africa, Nigeria and Ghana are at the top. For a production emergence in third world, main obstacles lies at the level of patents and licenses. In Senegal, where 85 to $90 \%$ of drug used are imported, difficulties are related to registration, competition of imported products, and especially the lack of regional purchasing power stations weigh on the local industries.

Today, where an incentive tax regime exists in Senegal, uniform act would be an opportunity to create new pharmaceutical companies.
\end{abstract}

Keywords: Pharmaceutical industry - article L596 - uniform act - drug - Shareholders' agreements - Carriage agreement. 


\section{INTRODUCTION}

Pharmaceutical industry in France stems from pharmacy practice. However, Germinal Act of year XI (1803) was not favorable to its promotion, because participation on activities and resources from non-pharmacists took an illegal character [1]. In 1852, Dorvault [2] founded Central Pharmacy, considered as an institution of public interest. This legislation, unsuited to industry development, will remain for a very long time. In 1937, François Prévet proposed a regime that would allow manufacturer to call on non-qualified capitalists provided, but the graduate retained his preponderance, independence and responsibility [3]. Due to certain constraints, Germinal Act will apply until 1941. Ordinance of May 23, 1945, creates three types of pharmaceutical establishments [4] (manufacturers, wholesalers, depositories), but the nongraduated capitalists imposed their point of view, because of their financial pre-eminence. However, decree application of February 5, 1960, of ordinance of February 4, 1959, provided that companies owning pharmaceutical establishments should be controlled by pharmacists who are said to be responsible [5]. With decree of September 1, 1961, rules have changed. Diploma of pharmacist was required only for two members of the board of directors; the general director may not be a pharmacist provided that his or her deputy director or other member of the board of directors appointed by him or her [6]. The Order of September 23, 1967 cancels decree of September 1961 for excess of power [7] and stipulates that pharmaceutical establishments must be owned by a pharmacist or have a general management in which a pharmacist participates. It is the pharmacist responsible. In joint-stock companies, they had to be pharmacists the president and half plus one of the members of the board of directors [8]. In Senegal, these old provisions were taken over by article L596 of Book V - Pharmacy still in force. Industrial pharmaceutical sector is slow to take off due to combination of several factors that could not encourage private nationals to invest in creation of local units for industrial production of medicines. In addition, there is a dependence of our country on major global producers of medicines for the management of major pandemics, chronic diseases, neonatal, infant-juvenile and maternal health [9]. Most of our medicines come from Asian, American, European and Maghreb industries, which supply more than $80 \%$ of our drug needs, compared to "10 to $15 \% "$ for our local industries. As the pharmaceutical industry is a high-value-added and wealth-creating sector in developed countries [10], it is essential to promote its development at local level, to ensure that our country has a sustainable coverage of generic drug needs. The objective of our publication is to contribute to the development of the local pharmaceutical industry. 


\section{Main Objective}

Encourage contractual freedom to develop pharmaceutical industry in Senegal

\section{Specific Objectives}

- Ensure pharmaceutical industry overview;

- Promote creation of pharmaceutical companies according to contractual freedom.

\section{METHODOLOGY}

- Review of the literature on the pharmaceutical industry;

- Review of Uniform Act on commercial companies and economic interest grouping (AUSCGIE) which encourage pharmaceutical companies creation.

\section{RESULTS AND DISCUSSION}

\section{Overview of pharmaceutical industry}

Pharmaceutical industry status in Senegal, will be studied through a review of the literature at global and African level in order to have a global idea on the subject, before addressing specific cases of Senegal for an objective sector analysis.

\section{Overview at global level}

Global level, we will present best laboratories situation, before conducting a sector review at Africa level.

\section{Situation of best laboratories in the world}

The purpose is to take stock of top ten laboratories in the world and to segment drug market.

\section{A. Inventory of pharmaceutical laboratories}

The classification of laboratories on the basis of their turnover into manufacturer's prices (excluding tax in millions of dollars) is summarized in Table I. It appears from this ranking that world market for the drug is held by the United States.

Table I. Ranking of top ten global pharmaceutical companies in 2014

\begin{tabular}{|c|c|c|c|}
\hline Rank & Companies & *Total sales PFHT (Md) & Covered market \\
\hline & Novartis (Suisse) & 50 & $5.5 \%$ \\
\hline & Pfizer (États Unis) & 44 & $4.8 \%$ \\
\hline & Sanofi (France) & 39 & $4.3 \%$ \\
\hline & Roche (Suisse) & 36 & $4.0 \%$ \\
\hline & Merck \& Co (États Unis) & 36 & $4.0 \%$ \\
\hline & Johnson \& Johnson (États Unis) & 36 & $4.0 \%$ \\
\hline & Astra Zeneca (Royaume Uni) & 33 & $3.6 \%$ \\
\hline & Glaxosmithkline (Royaume Uni) & 31 & $3.4 \%$ \\
\hline & Teva (Israël) & 25 & $2.7 \%$ \\
\hline & Gilead (États Unis) & 24 & $2.6 \%$ \\
\hline
\end{tabular}

Data source : IMS Health * Total manufacturers sale without tax in million dollars. 
B. World drug market

In 2014, medicines companies association estimated global drug market to be around \$ 910 billion in sales in 2014 (compared to less than \$ 200 billion in 1990); an increase of 8.8\% compared to 2013.

US market remains the largest with $41 \%$ of the world market, far ahead of the main European markets (Germany, France, Italy, the United Kingdom and Spain), accounting for 17\%, Japan 8\% and emerging countries (China and Brazil) 11\% market share [11].

2. Pharmaceutical industry in West Africa

Africa is the second most dynamic market in the world after Asia-Pacific region, with an average annual growth rate of over $10 \%$ [12]. Thus, within the framework of a vision, it is important to have an idea about potential of West African pharmaceutical industry (A), to better approach our challenges(B).

\section{A. Pharmaceutical industry in West Africa}

WHO has developed three indicators to monitor pharmaceutical production. Thus, the distribution of pharmaceutical industry potential in West African countries [13] (Table II).

Table II: Distribution of Pharmaceutical Industry potential in west Africa

\begin{tabular}{llll}
\hline Countries & Number of production units & Needs cover & Rank \\
Nigeria & 130 units & $50 \%$ & 1 \\
Ghana & 30 units & 25 to $30 \%$ & 2 \\
Sénégal & Pfizer, Valda, Sanofi-Aventis & Unavailable & $\mathbf{3}$ \\
Côte d'Ivoire & 5 units & $8 \%$ & $\mathbf{4}$ \\
Bénin & At least one (1) & Unavailable & $\mathbf{5}$ \\
Mali & 1 (state factory) & Unavailable & $\mathbf{6}$ \\
Burkina Faso & 1 (massive solution) & Unavailable & 7 \\
\hline
\end{tabular}

B. Challenges

Since production is low and without real economic stakes in the region, data collected are often imprecise and insufficient to allow a good sectorial analysis [14]. However, since the challenge is to combine profit and poverty, profitability demands of pharmaceutical industry do not leave much hope for our populations who can't afford expensive medicines. Faced with this context, Africa needs an emerging local pharmaceutical industry, and there are significant opportunities at this level. Indeed, Mr. MTHULI NCUBE chief economist of African development bank said : "Although African pharmaceutical market represents only $2 \%$ of global market [15], its growth remains the most important in the world". Therefore, it will be necessary to support and promote local production of medicines in Africa. Of course, local production of medicines does not make countries completely self-sufficient, but this would reduce dependencies. 


\section{I.1.2 Overview at Senegal level}

Given our country's dependence on medicines supply to the north, it is essential, before meeting our needs, to make an inventory at local level (A), by identifying constraints (B ) to meet future challenges.

1. The local medicines market

The local pharmaceutical market is estimated at about 58 billion CFA francs. 85 to $90 \%$ of medicines used are imported through national pharmacy of Supply and regional pharmacies, (public sector) and wholesale distributors Laborex, Ubipharm, Sodipharm, Ecopharm, Sogen and Duopharm (private sector).

As for demand, only $10 \%$ is covered by local production [16].

a. Aventis Pharma (repurchased by Medis), which covers $20 \%$ of local production with a turnover of 5.3 billion CFA francs;

b. Pfizer West Africa, which covers $10 \%$ of local production, with a turnover of 3 billion in 2000;

c. Laboratory Canonne (Valdafrique) with a turnover of 3.5 billion CFA Francs, of which $25 \%$ export;

d. West Africa Pharma;

e. Institut Pasteur in Dakar with a production capacity of 16 million doses of yellow fever vaccines [17].

\section{Constraints of local production}

The problem lies at the level of patents and licenses, which are the main handicap for the emergence of a production in the third world. Also there is tax and customs pressure weigh on industries (common external tarif). There is also a lack of investment incentives, difficulties in registering and applications fees for marketing authorization, fierce competition from imported products, and above all the absence of purchasing centers at regional level [18].

\section{II.2 Strategies for development of local drug production}

In Senegal, there is a real need for a local pharmaceutical industry emergence through creation of new drug companies. According to Uniform act [19] a company is a contract. Indeed, a company is a contract and contractual freedom under Senegalese law exists. In principle, any company is based on a company de facto in law ${ }^{1}$ except in one-person companies ${ }^{2}$. This freedom, permitted by law, may enable establishment of agreements or share agreements in the societal sphere.

There are also shareholders ${ }^{3}$ 'or shareholders' pacts $^{4}$. It is a contract that dictates how company will operate. However, problem is how to use it, and also how to take advantage of contractual 
freedom under a binding law such as article L. 596. In societal matters published articles of incorporation are opposable and valid for all partners. There are two things: First there are pacts to be provided besides statutes which may derogate from general rules in particular situations. Second, it is also possible to establish a portage agreement (II.2) by the will of parties.

Pacts are contracts governed by contractual freedom, while statutes are governed by law. In societal context, there are articles of incorporation which are published and opposable to all partners. However, besides these statutes, there are pacts which are essential to foresee, required in particular situations, and are derogatory to general rules. The pact is a contract that overlaps status to make it more flexible. People are drafting statutes and next to these statutes, we will have all shareholders or some of them who will agree to make a contract by which they will essentially say two things: First, an agreement to provide that if one of the parties to the pact wishes to sell its shares, it undertakes to offer them primarily to the others. It may also be prohibited from selling its shares. This is the most frequent pact agreement, called preferential right or right of pre-emption. As another type of agreement, it's the way in which we will exercise voting rights in society; for example, it may be foreseen that signatories shall appoint as head of company such person who may also be one of the signatories of the pact or a representative of one of the signatories of the pact. At this level, it will suffice to include in the pacts that only qualified pharmacist can be appointed in the governing bodies for the company organization and operation. However, the extrasatutary pacts have two advantages: First is that we can predict how the company will be run, or it will operate even before general meetings, especially for reasons of predictability.

Second advantage is that we will be able to retain control of the company because shareholders who are signatories to the pact can represent majority of shares, fifty plus one; then if they stipulate in their pact that none of them will give up their shares without first proposing them to a signatory of the pact, they will be guaranteed to retain control of the company even if they do not have $100 \%$ actions. With the fifty and a few percent they control through the pact, they're going to have a block of control. Moreover, the main interest of the pact is to bring people together under derogatory conditions in order to obtain necessary fidelity, investment or commitment from them. Also, pacts can be changed whenever desired, to bring in or enhance someone else's certain benefits ${ }^{5}$. Thus, there are generally two main themes in shareholders' pacts. It's related to the transfer of title. The financial investor wants to ensure presence of company founders, and thus provide clauses of accessibilities for the latter and for a certain duration, in order to guarantee their presence. There are also pre-emption clauses relating to priority, where 
shareholder wishes to sell his securities to a third party. Liquidity clauses so that the financial shareholder can recover a capital gain from his investment.

\section{II.2.2 Carriage Agreement}

Legislation does not mention ${ }^{6}$ this, but jurisprudence recognizes it except for fraud or unlawful motive. For this purpose, a carriage agreement ${ }^{7}$ is proposed as a solution to article L.596. One of carriage agreement objectives is not to reveal that one is associated in a company. In other words, people are asked to carry shares or shares of a company for themselves. There is a principal and a holder. The principal shall ask the holder to subscribe ${ }^{8}$ for or purchase ${ }^{9}$ on his behalf shares in a company. The holder will become a shareholder, if the principal allows. The client has the possibility to leave it free to manage its shares or not, by asking it on one hand that it returns to him all the dividends paid by the company and, on the other hand, to give him instructions ( voting instructions at meetings), after transmission of the information. It is a nominee agreement whose purpose is not to disclose that principal may invest in the company and have majority of shares because article L 596 prohibits it. However, it is important to note that if the company's by-laws provide for an accreditation clause, a clause in the articles of association of a corporation to say that if a person wishes to become a shareholder or the Company shall be authorized by the Board of Directors or by the meeting of the Company ${ }^{10}$, carriage agreement shall not be allowed and shall constitute a fraud on the approval clause. The purpose of this type of clause is to verify that persons who are shareholders in the company are persons known and accepted by existing partners. A non-pharmacist for example who wants to integrate the company, will not be accepted by partners. But apart from the fraudulent or illegal purpose, case law recognizes validity of carrier agreement. In addition, an agreement is provided for the termination of carrier agreement. A cross promise of purchase and sale granted in identical terms in the time of the shares. In principle, the bearer, even if he is legally the shareholder, does not incur any economic risk in the event of loss of value of the shares. It is only a favour to the true shareholder. It is the client who runs risk loss of value economically; but at the same time the bearer does not have possibility of enrichment if the shares had just increased.

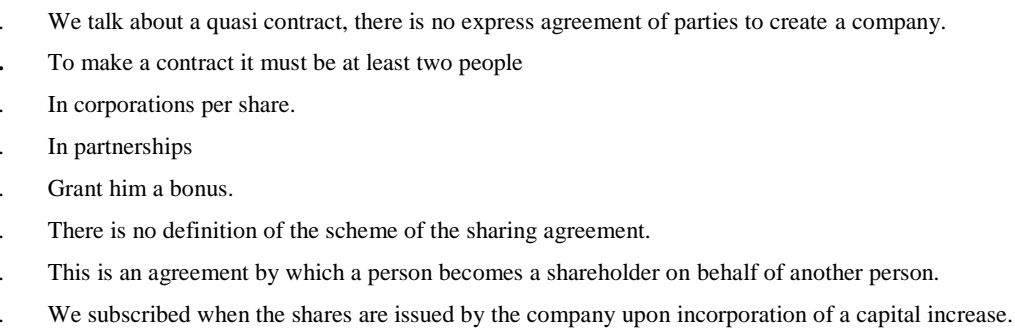


9. We do not buy shares already sold to the company or not.

10. To become a partner, you must have the approval of an organ of society.

\section{CONCLUSION}

The sub-regional market size and its economic weight may motivate a transfer of technology to a network of local production and distribution companies. Moreover, pharmaceutical industries are significant financial powers that contribute largely to the wealth creation of countries. In context of global economic crisis, where economic competitiveness of businesses has become central, all measures that can advance our businesses are essential to our national economy. In Senegal, where an incentive tax regime does not discriminate between domestic and foreign investors, pharmaceutical industry is slow to take off because of several factors that couldn't encourage private to invest in creation of pharmaceutical companies. Therefore, in view of local pharmaceutical industry development, uniform act would be an opportunity, without derogating from article L.596.

\section{REFERENCES}

1. P. Wilson-Carli, Evolution and orientation of French pharmacy, Th. Doct. Pharm. Aix Marseille, 1954, p. 99.

2. F. Dorvault, Officine. General Directory of Practical Pharmacy, Paris, Vigot Frères éditeurs, 1945.

3. F. Prévet, Essay on the practice of pharmacy applied to the pharmaceutical industry, Paris, Sirey, 1937.

4. G. Dillemann, H. Bonnemain et A. Boucherle, French Pharmacy: origin, history, evolution, Paris, Ed Tec \& Doc Lavoisier, 1992, p 114-117.

5. Henri Bonnemain, Bruno Bonnemain, «Relationship between the pharmaceutical industry and governments in France over the last two centuries: freedom to probation», History Review of Pharmacy, 90, 334, 2002, pp. 239-256.

6. Diploma of pharmacist was required only for two members of the board of directors; the general director may not be a pharmacist provided that his or her deputy director or other member of the board of directors appointed by him or her is.

7. Ordinance of 23 September 1967 stipulates that pharmaceutical establishments must be owned by a pharmacist or have a general management in which a pharmacist participates (Decree of 2 January 1969).

8. It is the pharmacist responsible. In joint-stock companies, they had to be pharmacists the president and half plus one of the members of the board of directors. 
9. http://www.seneweb.com/news/Sante/pharmacie-medicaments-le-senegal-importe-80-deses-besoins_n_96692.html (consulté le 20 octobre 2016)

10. https://www.mypharma-editions.com/le-top-10-classement-mondial-des-laboratoirespharmaceutiques-en-2014 (consulté en 2017). 50\% of all medicines produced worldwide (Novartis, Pfizer, Sanofi, Roche, Merck, Johnson and Johnson, Astrazeneca, Glaxo (GSK) among other new actor with the arrival of generics.

11. https://www.mypharma-editions.com/le-top-10-classement-mondial-des-laboratoirespharmaceutiques-en-2014 (consulté en 2017).

12. African pharmaceutical industry promises a bright future. http://www.afdb.org/fr/newsand-events/article/public-private-partnerships-promise-a-bright-future-for-the-africanpharmaceutical-industry-12318/ (consulté en 2017)

13. WHO monitoring indicators for pharmaceutical production (indicateurs généraux, structurels et de performance), afin de mesurer les performances de ce secteur. http ://www.ictsd.org/bridgesnews/passerelles/news/l \%E2 \%80 \%99industrie-

pharmaceutique-et-la-production-pharmaceutique-en-afrique (consulté le 20 octobre 2017).

14. Pharmaceutical industry and pharmaceutical production in West Africa: Potential constraints and prospects for evolution. http ://www.ictsd.org/bridgesnews/passerelles/news/1 \%E2 \%80 \%99industrie-

pharmaceutique-et-la-production-pharmaceutique-en-afrique (consulté le 20 octobre 2017).

15. African pharmaceutical industry promises a bright future. http://www.afdb.org/fr/newsand-events/article/public-private-partnerships-promise-a-bright-future-for-the-africanpharmaceutical-industry-12318/ (consulté en 2017). "Although African pharmaceutical market represents only $2 \%$ of global market, its growth remains the most important in the world".

16. http://hm.pharmaconsulting.overblog.com/pages/Projet_Usine_de_Production_ phamaceutique_au_Senegal-3174800.html (consulté le 20 octobre 2016)

17. Institut Pasteur in Dakar with a production capacity of 16 million doses of yellow fever vaccines.http://hm.pharmaconsulting.overblog.com/pages/Projet_Usine_de_Production_ phamaceutique_au_Senegal-3174800.html (consulté le 20 octobre 2016).

18. Constraints of local production. Pharmaceutical industry and pharmaceutical production in West Africa: Potential constraints and prospects for evolution. 
http ://www.ictsd.org/bridgesnews/passerelles/news/1 \%E2 \%80 \%99industrie-

pharmaceutique-et-la-production-pharmaceutique-en-afrique (consulté le 20 octobre 2017).

19. Revised Uniform Act relating to commercial companies and economic interest group adopted January 30, 2014 in Ouagadougou (Burkina Faso)

AJPHR is

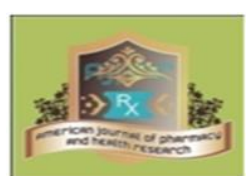

Peer-reviewed

monthly

Rapid publication

Submit your next manuscript at

editor@ajphr.com / editor.ajphr@gmail.com 